\title{
Ground penetrating radar for underground sensing in agriculture: a review**
}

\author{
Xiuwei Liu, Xuejun Dong*, and Daniel I. Leskovar \\ Texas A\&M AgriLife Research, Uvalde, Texas 78801, USA \\ Received March 14, 2016; accepted August 23, 2016
}

\begin{abstract}
A b s t r a c t. Belowground properties strongly affect agricultural productivity. Traditional methods for quantifying belowground properties are destructive, labor-intensive and pointbased. Ground penetrating radar can provide non-invasive, areal, and repeatable underground measurements. This article reviews the application of ground penetrating radar for soil and root measurements and discusses potential approaches to overcome challenges facing ground penetrating radar-based sensing in agriculture, especially for soil physical characteristics and crop root measurements. Though advanced data-analysis has been developed for ground penetrating radar-based sensing of soil moisture and soil clay content in civil engineering and geosciences, it has not been used widely in agricultural research. Also, past studies using ground penetrating radar in root research have been focused mainly on coarse root measurement. Currently, it is difficult to measure individual crop roots directly using ground penetrating radar, but it is possible to sense root cohorts within a soil volume grid as a functional constituent modifying bulk soil dielectric permittivity. Alternatively, ground penetrating radarbased sensing of soil water content, soil nutrition and texture can be utilized to inversely estimate root development by coupling soil water flow modeling with the seasonality of plant root growth patterns. Further benefits of ground penetrating radar applications in agriculture rely on the knowledge, discovery, and integration among differing disciplines adapted to research in agricultural management.
\end{abstract}

$\mathrm{K}$ e y w o r d s: ground penetrating radar, post-data analysis, crop roots, soil water content, soil texture

\section{INTRODUCTION}

The interactions and feedback between soil and plants affect the biogeochemical processes and biomass production in agriculture (Amundson et al., 2007). The ability

*Corresponding author e-mail: xuejun.dong@ag.tamu.edu

**This paper is part of the Texas A\&M AgriLife Research cropping system project entitled 'Root-shoot phenotyping and water balance characterization to improve water use efficiency and productivity of cropping systems in Texas' and Texas A\&M AgriLife Research Hatch project TEX09574 funded by the USDA NIFA, 2014-2019. of world food production to supply the increasing global population hinges on a steady increase in crop resource-use efficiency in the shallow subsurface of the earth (Morison et al., 2008). Plant roots take up essential water and nutrients from the soil, and the soil condition in turn affects plant root distribution and function (Hopmans and Bristow, 2002; Liu et al., 2015; Sharma et al., 2014; Zhang et al., 2009). New insights into belowground properties such as crop root distribution and soil water movements will benefit agricultural crop productivity.

Traditional methods to measure underground parts include excavation and sampling using soil cores or augers (Veihmeyer and Hendrickson, 1946; Frevert and Kirkham, 1949; Welbank and Williams, 1968). These standard methods sometimes can be the only way to measure soil characteristics with appropriate accuracy for a particular depth and point in space. But they are destructive, labor-consuming and expensive (Castro et al., 2015; Nanni and Demattê, 2006). Additionally, these methods usually do not allow long-term repeatable measurements (Danjon and Reubens, 2008). Other methods for belowground measurements include the use of soil moisture sensors (Baker and Allmaras, 1990; Dean et al., 1987), soil conductivity meters (Rhoades and Corwin, 1981), soil compaction meters (Liu et al., 2015; 2016), the mini-rhizotron technique (Hansson and Andrén, 1987; Sharma et al., 2014; Upchurch and Ritchie, 1983) and digital root imaging (Clark et al., 2011). Though some applications combine traditional methods with new technologies to allow efficient data acquisition (Herrero et al., 2003; Wagner et al., 1999), most of these sensor measurements represent point information such as soil moisture measurements as reviewed by Robinson et al. (2008). In fact, due to the temporal and spatial variability of soil characteristics such as soil water in the field (Jackson

(C) 2016 Institute of Agrophysics, Polish Academy of Sciences 
and Le Vine, 1996; Ritsema and Dekker, 1998), it is difficult to extrapolate point measurement to the field scale. Satellite-based microwave remote sensing has good regional relevance but only captures soil characteristics at very shallow surface layer (Robinson et al., 2008; Wang and Qu, 2009). Geophysical techniques such as ground penetrating radar (GPR) and electrical resistance tomography are fast, nondestructive and on-site sensing tools that provide an excellent compromise between point-measurement and regional remote sensing (Daniels, 2004; Huisman et al., 2003; Ramirez et al., 1996).

Ground penetrating radar is designed to locate buried objects (Daniels, 2004) and has been used widely in civil engineering (Goodman, 1994; Maierhofer, 2003; Salucci et al., 2014), archaeological research (Conyers, 2013), geophysical investigations (Carrière et al., 2013; Davis and Annan, 1989; Jol et al., 1996) and tree root detection (Hruska et al., 1999; Butnor et al., 2001; Guo et al., 2013a). GPR has been proven to produce a real, rapid, highresolution and non-invasive measurement of underground features. However, despite its use in tree root sensing in the past 15 years, reports on agricultural crop root research using GPR have been limited (Thompson, 2014; Thompson et al., 2013). Most studies conducted in agriculture have focused on soil water measurement (Doolittle and Collins, 1995; Galagedara et al., 2005; Grote et al., 2003), owing to the rapid development in the knowledge of physical principles, methods of measurement, and post-data analysis tools in this research area (Robinson et al., 2008). Moreover, a frequency shift method in frequency domain analysis can analyze soil moisture and soil clay content easily based on GPR surveys (Benedetto, 2010; Benedetto and Tosti, 2013), but it is not yet to be used in agriculture. In crop physiology research, deep roots are generally considered beneficial for improved overall crop water use efficiency, yet more accurate information on root development is needed to design optimal root/shoot ratios in cropping systems (Amato and Ritchie, 2002; Blum, 2005; Wasson et al., 2012; Zaman-Allah et al., 2011). Accurate information on the spatial distribution of plant roots is critical for evaluating field management and new crop cultivars for improved water use efficiency.

The objectives of this review are twofold: 1) present the applications of GPR in underground measurements in soil-plant systems; 2) discuss the current challenges and possible solutions of using GPR in sensing fine roots for agricultural crop and water management.

\section{INTRODUCTION TO GPR}

As a geophysical technique, GPR uses electromagnetic radiation to locate objects or interfaces buried beneath the soil surface (Daniels, 2004). Generally, a GPR system has three components: transmitting and receiving antennas, a control unit with a computer and associated software, and a display unit (Conyers, 2013). The transmitting antenna generates radar pulses and propagates them into the ground. The objects buried in the ground absorb, reflect, or scatter the radar energy. After some travel time, a portion of emitted radiation returns to the receiving antenna, which is then analyzed using software. Digital signal processing techniques are routinely used to increase the signal/noise ratio so that the subsurface conditions are accurately conveyed and captured (Cassidy, 2009).

There is an abundance of literature on GPR theory and data processing (Annan, 1992; Daniels, 2004; Olhoeft, 2000). A particular focus of past studies can be found in civil engineering applications (Benedetto and Pajewski, 2015), geophysical detection (Rea and Knight, 1998), soil moisture measurements (Huisman et al., 2003; Qin et al., 2013; Van Dam, 2014), and plant coarse root detection (Guo et al., 2013a). Basic data processing steps may include: filtering, data/trace editing and 'rubber-band' interpolation, dewow filtering, time-zero correction, deconvolution, velocity analysis and depth conversion, elevation or topographic corrections, gain functions, migration, advanced imaging, attribute analysis, and numerical modeling (Cassidy, 2009).

\section{APPLICATION OF GPR IN THE SENSING OF SOIL PHYSICAL CHARACTERISTICS AND ROOTS}

As discussed earlier, some soil characteristics can be measured only by taking soil samples; here, we limit our discussion to the GPR sensing of physical soil properties such as soil clay content, soil moisture, and soil bulk density (Table 1). Most GPR root studies are on tree roots (coarse roots $>0.2 \mathrm{~cm}$ ); here, we attempt to extrapolate using information from research on tree roots to assist in the detection of fine roots in crops (Table 2).

\section{Sensing soils and roots}

GPR systems were specifically designed to chart soil depth and extent of diagnostic subsurface horizons (Doolittle, 1987). Previous studies have used GPR to accurately estimate soil depth in rocky forest soils (Sucre et al., 2011), measure the depth to and thickness of several types of soil horizons (Johnson et al., 1982), determine thickness and characterize depths of organic soil materials (Collins et al., 1986; Shih and Doolittle, 1984; Winkelbauer et al., 2011) and bedrock (Novakova et al., 2013). GPR can also be used to identify subsurface flow pathways (Gish et al., 2005; Guo et al., 2014; Freeland et al., 2006), detect animal burrows (Chlaib et al., 2014), investigate the water table depth (Mahmoudzadeh et al., 2012) and identify offsite movement of agrochemicals (Yoder et al., 2001). In agriculture, soil quality is a key factor related to agricultural sustainability. There are some research conducted to study soil microvariability (Collins and Doolittle, 1987), investigate soil variability including soil water, soil bulk density and texture (Truman et al., 1988), evaluate soil clay content 
T a b l e 1. Studies on the application of GPR to determine soil physical characteristics

\begin{tabular}{|c|c|c|c|c|c|c|}
\hline Target & $\begin{array}{c}\text { Antenna center } \\
\text { frequency } \\
(\mathrm{MHz})\end{array}$ & Soil type & Scan method & Other equipment & $\begin{array}{l}\text { Data analysis } \\
\text { method }\end{array}$ & Index/model \\
\hline \multirow[t]{2}{*}{ Soil clay content } & 500 & $2-25 \%$ clay & linear & no & $\begin{array}{l}\text { time and } \\
\text { frequency } \\
\text { domain }\end{array}$ & $\begin{array}{l}\text { frequency } \\
\text { spectra peaks }\end{array}$ \\
\hline & 600 & $7-30 \%$ clay & linear & no & $\begin{array}{l}\text { frequency } \\
\text { domain }\end{array}$ & frequency peak \\
\hline Hard pan & 500 & $\begin{array}{l}\text { sandy loam and } \\
\text { clay loam }\end{array}$ & - & no & - & - \\
\hline $\begin{array}{l}\text { Soil bulk } \\
\text { density/ soil } \\
\text { moisture }\end{array}$ & 400 & sandy loam & linear & no & $\begin{array}{l}\text { frequency } \\
\text { domain }\end{array}$ & power spectrum \\
\hline \multirow[t]{4}{*}{$\begin{array}{l}\text { Soil resistance/ } \\
\text { soil water }\end{array}$} & 400 & silty loam & linear & EMI & time domain & $\begin{array}{l}\text { no/Topp } \\
\text { equation }\end{array}$ \\
\hline & 1000 & sand & linear & no & time domain & Topp equation \\
\hline & 400 & sand & linear & TDR & time domain & mixing model \\
\hline & 2000 & sand & - & no & $\begin{array}{l}\text { time and } \\
\text { frequency } \\
\text { domain }\end{array}$ & $\begin{array}{l}\text { mixing model/ } \\
\text { full-wave } \\
\text { inversion }\end{array}$ \\
\hline \multirow[t]{3}{*}{ Soil moisture } & $200-800$ & silt clay & linear & FDR & time domain & $\begin{array}{l}\text { full wave model, } \\
\text { mixing model } \\
\text { and Debye } \\
\text { equation }\end{array}$ \\
\hline & 600 and 1600 & $\begin{array}{l}\text { sandy soil, } \\
\text { subgrade soil, } \\
5 \% \text { clay and } \\
20 \% \text { clay }\end{array}$ & linear & no & $\begin{array}{l}\text { frequency } \\
\text { domain }\end{array}$ & $\begin{array}{l}\text { peak of the } \\
\text { frequency }\end{array}$ \\
\hline & 600 and 1600 & sandy loam & linear & ERI & $\begin{array}{l}\text { time and } \\
\text { frequency } \\
\text { domain }\end{array}$ & $\begin{array}{l}\text { Topp equation, } \\
\text { peak of the } \\
\text { frequency }\end{array}$ \\
\hline
\end{tabular}

EMI - electromagnetic induction, TDR - time-domain reflectometry, FDR - frequency domain reflectometry, ERI - electrical resistivity imaging.

(West et al., 2003; Tosti et al., 2013), sense hard pan in the field (Raper et al., 1990), reveal biogenic gas accumulation (Comas et al., 2005), assess the inorganic pollutant contamination in groundwater (Wijewardana et al., 2015), and study soil salinity (Hagrey, 2000). The electromagnetic method can also be used for identifying the dynamic changes in available soil nitrate, as affected by animal manure and nitrate fertilizer treatments, during the corn-growing season (Eigenberg et al., 2002). Doolittle and Brevik (2014) summarized additional uses of electromagnetic induction techniques in soil studies. Generally, GPR can be used to monitor subsurface features that have contrasting dielectric constants (Truman et al., 1988). In particular, GPR has been used for soil water content estimation including measuring soil water content profile (Lambot et al., 2004), estimating soil water variation under irrigation conditions (Galagedara et al., 2005), identifying specific soil water depth and monitoring spatial and temporal variation of soil water content (Pan et al., 2012), mapping the spatial variation of soil water content at the field scale (Weihermüller et 
T a b l e 2. Recent studies on the application of GPR to detect root characteristics (scan method - linear, data analysis method - time domain)

\begin{tabular}{|c|c|c|c|c|}
\hline Target & $\begin{array}{c}\text { Antenna center } \\
\text { frequency } \\
(\mathrm{MHz})\end{array}$ & Soil type & Other equipment & Index \\
\hline $\begin{array}{l}\text { Root diameter } \\
\text { and root biomass }\end{array}$ & 500 and 800 & $\begin{array}{l}\text { brown forest } \\
\text { soil }\end{array}$ & TDR & $\begin{array}{l}\text { pixels within threshold range, high amplitude area, } \\
\text { time interval, magnitude width }\end{array}$ \\
\hline Root diameter & 900 & sandy clay soil & no & $\begin{array}{l}\text { sum of amplitude areas and amplitude area for the } \\
\text { maximum reflection waveform }\end{array}$ \\
\hline $\begin{array}{l}\text { Root biomass and } \\
\text { root architecture }\end{array}$ & 1000 & silt loam & TDR & reflection intensity \\
\hline Root diameter & 1500 & sandy soil & no & $\begin{array}{l}\text { amplitude of reflected wave, time interval, amplitude } \\
\text { area of reflected wave, threshold area }\end{array}$ \\
\hline \multirow[b]{2}{*}{ Root biomass } & 1000 & sandy loam & no & pixel intensity \\
\hline & $\begin{array}{l}500,900 \\
\text { and } 2000\end{array}$ & sandy soil & no & $\begin{array}{l}\text { pixels within the threshold range and high amplitude } \\
\text { area }\end{array}$ \\
\hline $\begin{array}{l}\text { Root diameter } \\
\text { and root depth }\end{array}$ & 900 & granitic soil & ThetaProbe & $\begin{array}{l}\text { maximum amplitude, time interval and magnitude } \\
\text { area }\end{array}$ \\
\hline Root detection & 900 & sand & no & amplitude area and time interval \\
\hline Root biomass & 1500 & $\begin{array}{l}\text { sand, sandy } \\
\text { loam and sandy } \\
\text { clay }\end{array}$ & no & intensity threshold \\
\hline Root number & 900 & sandy loam & no & patterns in the radargrams \\
\hline
\end{tabular}

Explanation as in Table 1.

al., 2007), and comparing the tillage effects on soil water content (Jonard et al., 2013). Compared to time domain reflectometry, GPR is better suited for mapping large-scale features ( $>5 \mathrm{~m}$ ) in soil water content (Huisman et al., 2002). The precision of GPR used to measure soil water content can vary from $0.0026 \mathrm{~cm}^{3} \mathrm{~cm}^{-3}$ (Stoffregen et al., 2002) to $0.115 \mathrm{~cm}^{3} \mathrm{~cm}^{-3}$ (Weihermüller et al., 2007) depending on soil conditions and GPR antenna configuration. Using a $100 \mathrm{MHz}$ GPR, for example, Schmelzbach et al. (2012) obtained soil water information down to $7 \mathrm{~m}$ with decimeter resolution.

Some of recently published papers on root detection are summarized in Table 2. Recent applications of GPR for plant root detection have focused on coarse roots $(>0.2 \mathrm{~cm})$ (Guo et al., 2013a). Previous studies have shown that GPR can be used to estimate root diameter (Barton and Montagu, 2004; Cui et al., 2011), root biomass (Butnor et al., 2003; Guo et al., 2013c; Zhu et al., 2014), root zone area (Lorenzo et al., 2010) and root mapping (Hruska et al., 1999). In particular, Guo et al. (2013a) conducted a thorough review of the application of GPR for coarse root detection and quantification. They summarized the state of knowledge of coarse root measurement using GPR and discussed the potentials, constraints, and possible solutions to improve coarse root estimations.

\section{GPR equipment}

The judicial selection of the antenna is important because the size of a target detectable with a GPR depends on the center frequency of the antenna. There is a trade-off between radar resolution and penetration depth. Generally, a high-frequency antenna will get a high resolution of information on the objects within a shallow depth. A lowfrequency antenna will get a low resolution of information but can propagate deeper into soil layers. A wide range of antenna frequencies are used because they focus on different objects (Tables 1 and 2).

\section{GPR measuring environment}

Soil suitability maps for GPR application was developed in the United States based on data of soil electrical conductivity which is influenced by soil clay content, electrical conductivity, sodium absorption ratio, and calcium carbonate content (Doolittle et al., 2002, 2007). This map can provide a quick overview of soil properties that affect the application of GPR in a broad area. However, it does not mean GPR cannot be used in the unsuited area. The actual performance and effectiveness of GPR application will depend on local site conditions (Goodman et al., 2006), characteristics 
of subsurface target (Doolittle et al., 2002; Weaver, 2006), the strategy of setting up survey grids (Pomfret, 2006), as well as data processing technique (Benedetto and Pajewski, 2015). Soil dielectric permittivity and electrical conductivity are the two key factors affecting the GPR signal (Daniels, 2004). A large contrast between the soil and buried objects helps GPR to capture the target information. Generally, GPR is most useful in low electrical-loss materials because a large portion of the transmitted electromagnetic radiation is reflected and captured by the receiving antenna, making the buried objects more detectable (Jol, 2008). Therefore, most studies on plant roots have been conducted in sandy loam soil and dry conditions (Borden et al., 2014; Butnor et al., 2003; Barton and Montagu, 2004; Hirano et al., 2009). Some studies show that soil water measurements are more feasible in sandy soils as compared to loamy sand and silty clay soil (Stoffregen et al., 2002). In a field with soil containing high silt and clay, GPR cannot provide adequate spatial information on soil water content (Weihermüller et al., 2007). Soils with high water, clay and soluble salt contents have high dielectric permittivity and electrical conductivity, which could decrease the electromagnetic gradient between soil and buried objects (Butnor et al., 2001, 2005; Hagrey, 2000). Actually, the very nature of water, clay and soluble salts can be utilized to characterize significant changes in root zone features based on contrasts in dielectric permittivity (Topp et al., 1980) and the Rayleigh scattering phenomenon (Benedetto, 2010; Benedetto and Tosti, 2013).

\section{Post-data analysis}

GPR data analysis can be conducted in time domain or frequency domain (Benedetto and Pajewski, 2015) to get a useful index reflecting the buried objects. Generally, two main groups of indexes can be extracted from the radargrams for coarse root estimation: (a) the reflection strength indexes, such as areas within threshold range, pixels within threshold and mean pixel; (b) the reflection waveform indexes from reflected signals such as amplitude of reflected wave, high amplitude areas and time interval between zero crossing (Guo et al., 2013a). Also pattern of radargrams can be used to detect root number (Table 2). Values of dielectric permittivity can be obtained by computing the delay time of reflections once the value for the velocity propagation of the wave in the soil is determined (Benedetto and Benedetto, 2002) and soil water content can be estimated using Topp petrophysical equation, a dielectric mixing model, or a full wave model (Table 1). These models for the estimation of soil physical characteristics are based on permittivity measurements.

Another more efficient and accurate approach to measuring soil water and clay content used in civil engineering is the frequency shift method (Benedetto, 2010; Benedetto and Tosti, 2013). This method does not need calibration to estimate soil moisture and clay content. As soil water or clay content increases, the frequency spectrum will shift from high to low frequency (Benedetto, 2010; Benedetto and Tosti, 2013; Tosti et al., 2013) (Table 1).

\section{CHALLENGES AND POTENTIAL SOLUTIONS OF USING GPR IN AGRICULTURE}

Despite progress made in GPR applications in engineering and forestry in past 20 years, the use of GPR technology to assist agricultural crop production has been very limited. There are challenges, such as the inability of GPR to detect individual fine roots of most agricultural crops as well as detecting roots buried deep in the soil profile, but ample opportunities exist to integrate current research methodologies from soil science, forestry and engineering to agricultural applications.

\section{Developing more advanced GPR methods for belowground measurements in agriculture}

Soil and root features interested in agricultural research mostly locate within top 2 meter of soil. Combined use of antennas of high (such as 1-2 GHz) and low (400-600 MHz) frequencies should be useful in exploring the interested soil depth, constrained by the afore-mentioned resolution vs. penetrating depth trade-off and local soil condition. Almost all of the previous studies used linear measurements because the current radar system is designed only for linear data analysis (Tables 1 and 2). Sometimes this method cannot fully capture the characteristics of buried roots if their orientation is parallel to the downward direction of the GPR wave propagation (Guo et al., 2013a). While some scientists have tried to use circular scanning to better detect the buried objects (Zenone et al., 2008), more effective software tools are still needed to extract root information (Guo et al., 2013a).

In an agricultural field, the interactions underground can be very complex. For example, soil water, soil texture and soil compaction all may affect plant root distribution. As the original GPR transmitted electromagnetic pulses are modified at multiple frequencies, the returned signals carry influences from various sources (Cui et al., 2015). Wavelet multiresolution analysis, a mathematical technique whereby natural signals are systematically partitioned into different frequency components with varying window sizes appropriate for different scales, has been shown to be useful for GPR signal de-noising and physical information extraction in engineering (Baili et al., 2009; Oskooi et al., 2014; Walker, 2008). At the same time, as data processing using various wavelet thresholding algorithms tend to remove the high-frequency components from the original signal (Dong et al., 2008; Oskooi et al., 2014), the efficacy may be limited for uncovering subtle features of objects. To get around this influence, alternative signal partitioning methods, such as wavelet packet decomposition (Walker, 2008), may be used to preserve portions of the high-frequency signals that 
might otherwise be removed as part of the signal noises in traditional dyadic wavelet decomposition procedures. Also, algorithms for the systematic sampling of the returned GPR spectrum are needed to correlate more effectively the GPR frequency bands with the target objects.

Forward simulation is another useful method to capture the response of GPR signal to interested underground part. By forward simulation, radar responses to specific soil characters can be modeled, making possible the differentiation of unexpected signals (Guo et al., 2013b). Though not new in GPR data analysis (Giannopoulos, 2005; Goodman, 1994), more investigations are still needed to build forward simulation algorithms to address different research objectives.

\section{Sensing fine roots: a paradigm change from detecting single roots to capturing root cohorts and xylem-hydro-coherence}

Plant root research using GPR is focused currently on coarse roots because the minimum detectable root size is 0.25-0.5 cm for high frequency antenna (1 500-2 $000 \mathrm{MHz})$ (Cui et al., 2011; Wielopolski et al., 2000). For most agricultural field crops, however, fine roots are more important than coarse roots in terms of water and nutrient uptake. For example, most root diameter sizes of wheat, corn and soybean are less than $0.033,0.50,0.125 \mathrm{~cm}$, respectively (Seversike et al., 2014; Wang et al., 2014, 2015). Even though many studies have used GPR successfully to measure coarse roots as discussed above, the physical principle behind the effect of roots on soil dielectric permittivity is presently unclear (Guo et al., 2013a). This limitation was also reported on tree roots smaller than $0.1 \mathrm{~cm}$ (Hirano et al., 2009). Therefore, GPR may not detect individual fine crop roots directly. However, for root phenotyping, parameters describing root cohorts, such as root biomass, root length, density or root distribution patterns, are equally important as those describing the architecture of an individual root, such as root angle and root diameter.

The embedment of fine roots in the soil matrix profoundly changes soil physical properties. Fine roots increase the macropore spaces due to the creation of air spaces between root micro-tunnels and the bulk soil structure. Thompson (2014) used GPR to successfully differentiate wheat root mass from soil under field conditions. Another important feature that fine roots bring to the soil system is the waterfilled xylem hydro-coherence structure, especially for crops under normal management in which the xylem water potential is maintained within a hydraulic safety threshold (Holloway-Phillips and Brodribb, 2011). Because water has a significantly higher dielectric permittivity than many soil-borne materials such as bio-cellulose (McDonald et al., 2002; Stoops, 1934) or soil minerals (Davis and Annan, 1989), the influence of the fine root xylem network to the soil dielectric permittivity should be captured by GPR at a bulk soil volume scale, instead of the individual root scale. However, the physical theory governing the interaction between the fine root xylem network and GPR-generated electromagnetic wave is unknown (Andrea Benedetto, personal communication). This calls for controlled experiments to provide firsthand empirical data in support of GPR-based fine root sensing.

In the field of agricultural crop improvement, characterizing root growth and distribution of newly developed genotypes and cultivars under field conditions, particularly for drought-prone environments, is important. Root distribution can help evaluate soil water status (Zhang et al., 2015); conversely, soil water distribution will help explain root characters if we know how much soil water is used by the crop. Soil nutrition, soil bulk density and texture also influence root development (Wang et al., 2013; Zhang et al., 2012; Liu et al., 2015). The capability of GPR to capture soil characteristics, particularly soil water content and soil nutrition as main determinants of crop growth, provides new opportunities to improve fine root estimation with a hydrology-based inverse modeling approach. For decades, one effective way of estimating fine root development has been to use a macroscopic root uptake model in conjunction with soil water flow modeling (Feddes et al., 1978; Yadav and Mathur, 2008). In order to estimate root growth patterns along with unknown soil physical properties, various optimization approaches have been utilized based on measured soil water content data (Dong et al., 2010). The fact that most applications rely on point-measured soil water and physical properties makes it time-consuming and even difficult to reliably determine unknown parameters including root growth. In addition to non-invasiveness, GPR-based soil sensing also provides a good spatial averaging of soil features (as effectively illustrated in Figs 1-2 of Davis and Annan, 1989), which would be ideal for enhancing root growth estimation by macroscopic root uptake modeling. Finally, other geophysical sensing tools - electromagnetic induction, time-domain reflectometry, frequency domain reflectometry, and electrical resistivity imaging - can be used in combination with GPR to provide a more robust measurement of soil features (Tables 1 and 2).

\section{Knowledge integration for new GPR applications and development in agriculture}

The literature survey of this review highlights the contrast between the extensive use of the GPR sensing tools in engineering sciences and the meager data in agriculture (except for forest root surveys). Those applications in engineering sciences in which experimental methods were employed to calibrate the currently available GPR tools for detecting new features of soil and environment are especially of valuable for agricultural research. While experimental approach has been the strongest pillers supporting the advancement of agricultural and biological sciences, it seems that the recent trends of agricultural methodology are tinged with statistical considerations more than physical/biophysical 
ones. Manipulative experiments focused on physical considerations, such as that done in Benedetto and Tosti (2013), would allow agricultural researchers effectively establish the relations between GPR signal frequency bands and interested soil and plant features. Considering the near-term trend that GPR application and data interpretation in agriculture would remain less 'straightforward', GPR training courses should emphasis experimental approaches for assisting GPR signal interpretation, in addition to the routine topics of GPR operating principles. Without doubt, the new development in GPR hardware and software requires close collaborations between scientists working in geoscience or engineering and those in agriculture. For example, Dirk Hays (Texas A\&M University and AgriLife Research) is leading a U.S. Department of Energy project 'GroundPenetrating Radar (GPR) for Enhanced Root and Soil Organic Carbon Imaging', (http://aglifesciences.tamu.edu/ blog/2016/02/02/agrilife-research-to-take-ground-penetrating-research-to-new-crops/). Breeders, agronomists, rangeland ecologists, geoscientists, agricultural engineers and GPR equipment and software developers are working together in this project. This kind of cooperation is expected to enhance the application of GPR in agriculture, especially crop root measurements.

\section{SUMMARY}

Traditional methods for underground feature measurements are destructive, time-consuming and expensive. GPR is a non-invasive, on-site measurement technique with which we can get more accurate and complete underground information. Though GPR has been widely used in civil engineering, geosciences, and forestry, some of the advanced methods have not been adopted by agricultural soil research nor focused on root sensing. This review summarizes the application of GPR for soil/root detection and discusses the current challenges of using GPR in agriculture. Advanced data analysis methods for soil physical measurements are needed in the agricultural field. GPR sensing can be adapted and applied to further explore crop root characteristics and xylem-hydro-coherence. Finally, new development in GPR applications in agriculture will rely on successful collaboration between biological and engineering sciences.

Conflict of interest: Authors not declare conflict of interest.

\section{REFERENCES}

Amato M. and Ritchie J.T., 2002. Spatial distribution of roots and water uptake of maize (Zea mays L.) as affected by soil structure. Crop Sci., 42, 773-780.

Amundson R., Richter D.D., Humphreys G.S., Jobbágy E.G., and Gaillardet J., 2007. Coupling between biota and earth materials in the critical zone. Elements, 3, 327-332.
Annan A., 1992. Ground penetrating radar workshop notes. Sensors and Software Inc., Mississauga, Ontario, Canada.

Baili J., Lahouar S., Hergli M., Al-Qadi I.L., and Besbes K., 2009. GPR signal de-noising by discrete wavelet transform. NDT E Int., 42, 696-703.

Baker J. and Allmaras R., 1990. System for automating and multiplexing soil moisture measurement by time-domain reflectometry. Soil Sci. Soc. Am. J., 54, 1-6.

Barton C.V. and Montagu K.D., 2004. Detection of tree roots and determination of root diameters by ground penetrating radar under optimal conditions. Tree Physiol., 24, 1323-1331.

Benedetto A., 2010. Water content evaluation in unsaturated soil using GPR signal analysis in the frequency domain. J. Appl. Geophys., 71, 26-35.

Benedetto A. and Benedetto F., 2002. GPR experimental evaluation of subgrade soil characteristics for rehabilitation of roads. Proc. 9th Int. Conf. Ground Penetrating Radar (GPR2002), April 15, Santa Barbara, CA, USA, Int. Society for Optics and Photonics, 4758, 708-714.

Benedetto A. and Pajewski L., (Eds) 2015. Civil Engineering Applications of Ground Penetrating Radar. Springer International Publishing, Switzerland.

Benedetto F. and Tosti F., 2013. GPR spectral analysis for clay content evaluation by the frequency shift method. J. Appl. Geophys., 97, 89-96.

Blum A., 2005. Drought resistance, water-use efficiency, and yield potential - are they compatible, dissonant, or mutually exclusive? Crop Pasture Sci., 56, 1159-1168.

Borden K.A., Isaac M.E., Thevathasan N.V., Gordon A.M., and Thomas S.C., 2014. Estimating coarse root biomass with ground penetrating radar in a tree-based intercropping system. Agroforest. Syst., 88, 657-669.

Butnor J., Roth B., and Johnsen K., 2005. Feasibility of using ground-penetrating radar to quantify root mass in Florida's intensively managed pine plantations. Forest Biology Research Cooperative, 38, 13 pages. University of Florida, Gainesville, FL, USA.

Butnor J.R., Doolittle J., Johnsen K.H., Samuelson L., Stokes T., and Kress L., 2003. Utility of ground-penetrating radar as a root biomass survey tool in forest systems. Soil Sci. Soc. Am. J., 67, 1607-1615

Butnor J.R., Doolittle J., Kress L., Cohen S., and Johnsen K.H., 2001. Use of ground-penetrating radar to study tree roots in the southeastern United States. Tree Physiol., 21, 1269-1278.

Butnor J.R., Samuelson L.J., Stokes T.A., Johnsen K.H., Anderson P.H., and González-Benecke C.A., 2016. Surface-based GPR underestimates below-stump root biomass. Plant Soil, 402, 47-62.

Carrière S.D., Chalikakis K., Sénéchal G., Danquigny C., and Emblanch C., 2013. Combining electrical resistivity tomography and ground penetrating radar to study geological structuring of karst unsaturated zone. J. Appl. Geophys., 94, 31-41.

Cassidy N.J., 2009. Ground penetrating radar data processing, modelling and analysis. In: Ground Penetrating Radar Theory and Applications (Ed. H.M. Jol). Elsevier, Amsterdam, The Netherlands. 
Castro A.C.M., Meixedo J.P., Santos J.M., Góis J., BentoGonçalves A., Vieira A., and Lourenço L., 2015. On sampling collection procedure effectiveness for forest soil characterization. Flamma, 6, 98-100.

Chlaib H.K., Mahdi H., Al-Shukri H., Su M.M., Catakli A., and Abd N., 2014. Using ground penetrating radar in levee assessment to detect small scale animal burrows. J. Appl. Geophys., 103, 121-131.

Clark R.T., MacCurdy R.B., Jung J.K., Shaff J.E., McCouch S.R., Aneshansley D.J., and Kochian L.V., 2011. Threedimensional root phenotyping with a novel imaging and software platform. Plant Physiol., 156, 455-465.

Collins M., Schellentrager G., Doolittle J., and Shih S., 1986. Using ground-penetrating radar to study changes in soil map unit composition in selected Histosols. Soil Sci. Soc. Am. J., 50, 408-412.

Collins M.E. and Doolittle J.A., 1987. Using ground-penetrating radar to study soil microvariability. Soil Sci. Soc. Am. J., 51, 491-493.

Comas X., Slater L., and Reeve A., 2005. Spatial variability in biogenic gas accumulations in peat soils is revealed by ground penetrating radar (GPR). Geophysical Research Letters, 32, L08401.

Conyers L.B., 2013. Ground-penetrating radar for archaeology. Rowman and Littlefield Publishers, Alta Mira Press, Latham, MD, USA.

Cui F., Wu Z.Y., Wang L., and Wu Y.B., 2015. Application of the Ground Penetrating Radar ARMA power spectrum estimation method to detect moisture content and compactness values in sandy loam. J. Appl. Geophys., 120, 26-35.

Cui X., Chen J., Shen J., Cao X., Chen X., and Zhu X., 2011. Modeling tree root diameter and biomass by ground-penetrating radar. Sci. China Earth Sci., 54, 711-719.

Daniels D.J., 2004. Ground Penetrating Radar. The Institution of Engineering and Technology, London, UK.

Danjon F. and Reubens B., 2008. Assessing and analyzing 3D architecture of woody root systems, a review of methods and applications in tree and soil stability, resource acquisition and allocation. Plant Soil, 303, 1-34.

Davis J. and Annan A., 1989. Ground-penetrating radar for highresolution mapping of soil and rock stratigraphy. Geophys. Prospect., 37, 531-551.

Dean T., Bell J., and Baty A., 1987. Soil moisture measurement by an improved capacitance technique, Part I. Sensor design and performance. J. Hydrol., 93, 67-78.

Dong X., Nyren P., Patton B., Nyren A., Richardson J., and Maresca T., 2008. Wavelets for agriculture and biology: A tutorial with applications and outlook. BioScience, 58, 445-453.

Dong X., Patton B.D., Nyren A.C., Nyren P.E., and Prunty L.D., 2010. Quantifying root water extraction by rangeland plants through soil water modeling. Plant Soil, 335, 181-198.

Doolittle J.A., 1987. Using ground-penetrating radar to increase the quality and efficiency of soil surveys 1. Soil Survey Techniques. Soil Sci. Soc. America, Madison, WI, USA.

Doolittle J.A. and Brevik E.C., 2014. The use of electromagnetic induction techniques in soils studies. Geoderma, 223-225, $33-45$.
Doolittle J.A. and Collins M.E., 1995. Use of soil information to determine application of ground penetrating radar. J. Appl. Geophys., 33, 101-108.

Doolittle J.A., Minzenmayer F.E., Waltman S.W., and Benham E.C., 2002. Ground-penetrating radar soil suitability map of the conterminous United States (Eds S.K. Koppenjan, L. Hua). SPIE, 4158, 7-12, April 30-May 2, Santa Barbara, CA, USA.

Doolittle J.A., Minzenmayer F.E., Waltman S.W., Benham E.C., Tuttle J.W., and Peaslee S.D., 2007. Groundpenetrating radar soil suitability map of the conterminous United States. Geoderma, 141, 416-421.

Eigenberg R.A., Doran J.W., Nienaber J.A., Ferguson R.B., and Woodbury B.L., 2002. Electrical conductivity monitoring of soil condition and available $\mathrm{N}$ with animal manure and a cover crop. Agricult. Ecosyst. Environ., 88, 183-193.

Feddes R.A., Kowalik P.J., and Zaradny H., 1978. Simulation of field water use and crop yield. Centre for Agricultural Publishing and Documentation, Wageningen, The Netherlands.

Freeland R., Odhiambo L., Tyner J., Ammons J., and Wright W., 2006. Nonintrusive mapping of near-surface preferential flow. Appl. Eng. Agric., 22, 315-319.

Frevert R.K. and Kirkham D., 1949. A field method for measuring the permeability of soil below a water table. Proc. 28th Annual Meeting, Highway Research Board, Washington, DC, December 7-10, 1948, 28, 433-442.

Galagedara L., Parkin G., Redman J., Von Bertoldi P., and Endres A., 2005. Field studies of the GPR ground wave method for estimating soil water content during irrigation and drainage. J. Hydrol., 301, 182-197.

Giannopoulos A., 2005. Modelling ground penetrating radar by GprMax. Constr. Build. Mater., 19, 755-762.

Gish T., Walthall C., Daughtry C., and Kung K.J., 2005. Using soil moisture and spatial yield patterns to identify subsurface flow pathways. J. Environ. Qual., 34, 274-286.

Goodman D., 1994. Ground-penetrating radar simulation in engineering and archaeology. Geophys., 59, 224-232.

Goodman D., Nishimura Y., Hongo H., and Higashi N., 2006. Corrections for topography and the tilt of ground-penetrating radar antennae. Archaeol. Prospect., 13, 157-161.

Grote K., Hubbard S., and Rubin Y., 2003. Field-scale estimation of volumetric water content using ground-penetrating radar ground wave techniques. Wat. Resources Res., 39, 1321-1335.

Guo L., Chen J., Cui X., Fan B., and Lin H., 2013a. Application of ground penetrating radar for coarse root detection and quantification: a review. Plant Soil, 362, 1-23.

Guo L., Lin H., Fan B., Cui X., and Chen J., 2013b. Forward simulation of root's ground penetrating radar signal: simulator development and validation. Plant Soil, 372, 487-505.

Guo L., Lin H., Fan B., Cui X., and Chen J., 2013c. Impact of root water content on root biomass estimation using ground penetrating radar: evidence from forward simulations and field controlled experiments. Plant Soil, 371, 503-520. 
Guo L., Chen J., and Lin H., 2014. Subsurface lateral preferential flow network revealed by time-lapse ground-penetrating radar in a hillslope. Water Resour. Res., 50, 9127-9147.

Guo L., Wu Y., Chen J., Hirano Y., Tanikawa T., Li W., and Cui X., 2015. Calibrating the impact of root orientation on root quantification using ground-penetrating radar. Plant Soil, 395, 289-305.

Hagrey S.A. and Müller C., 2000. GPR study of pore water content and salinity in sand. Geophys. Prospect., 48, 63-85.

Hansson A.C. and Andrén O., 1987. Root dynamics in barley, lucerne and meadow fescue investigated with a mini-rhizotron technique. Plant Soil, 103, 33-38.

Herrero J., Ba A.A., and Aragüés R., 2003. Soil salinity and its distribution determined by soil sampling and electromagnetic techniques. Soil Use Manag., 19, 119-126.

Hirano Y., Dannoura M., Aono K., Igarashi T., Ishii M., Yamase K., Makita N., and Kanazawa Y., 2009. Limiting factors in the detection of tree roots using ground-penetrating radar. Plant Soil, 319, 15-24.

Hirano Y., Yamamoto R., Dannoura M., Aono K., Igarashi T., Ishii M., Yamase K., Makita N., and Kanazawa Y., 2012. Detection frequency of Pinus thunbergii roots by groundpenetrating radar is related to root biomass. Plant Soil, 360, 363-373.

Holloway-Phillips M. and Brodribb T.J., 2011. Minimum hydraulic safety leads to maximum water-use efficiency in a forage grass. Plant Cell Environ., 34, 302-313.

Hopmans J.W. and Bristow K.L., 2002. Current capabilities and future needs of root water and nutrient uptake modeling. Adv. Agron., 77, 103-183.

Hruska J., Čermák J., and Šustek S., 1999. Mapping tree root systems with ground-penetrating radar. Tree Physiol., 19, $125-130$

Huisman J., Hubbard S., Redman J., and Annan A., 2003. Measuring soil water content with ground penetrating radar. Vadose Zone J., 2, 476-491.

Huisman J., Snepvangers J., Bouten W., and Heuvelink G., 2002. Mapping spatial variation in surface soil water content: comparison of ground-penetrating radar and time domain reflectometry. J. Hydrol., 269, 194-207.

Jackson T. and Le Vine D.E., 1996. Mapping surface soil moisture using an aircraft-based passive microwave instrument: Algorithm and example. J. Hydrol., 184, 85-99.

Johnson R.W., Glasscum R., and Wojtasinski R., 1982. Application of ground penetrating radar to soil survey. Soil Horizons, 23, 17-25.

Jol H.M., 2008. Ground penetrating radar theory and applications. Elsevier, Amsterdam, The Netherlands.

Jol H.M., Smith D.G., and Meyers R.A., 1996. Digital ground penetrating radar (GPR): A new geophysical tool for coastal barrier research (examples from the Atlantic, Gulf and Pacific coasts, USA). J. Coastal Res., 12, 960-968.

Jonard F., Mahmoudzadeh M., Roisin C., Weihermüller L., André F., Minet J., Vereecken H., and Lambot S., 2013. Characterization of tillage effects on the spatial variation of soil properties using ground-penetrating radar and electromagnetic induction. Geoderma, 207, 310-322.
Lambot S., Rhebergen J., Van den Bosch I., Slob E., and Vanclooster M., 2004. Measuring the soil water content profile of a sandy soil with an off-ground monostatic ground penetrating radar. Vadose Zone J., 3, 1063-1071.

Liu X., Feike T., Shao L., Sun H., Chen S., and Zhang X., 2016. Effects of different irrigation regimes on soil compaction in a winter wheat-summer maize cropping system in the North China Plain. Catena, 137, 70-76.

Liu X., Zhang X., Chen S., Sun H., and Shao L., 2015. Subsoil compaction and irrigation regimes affect the root-shoot relation and grain yield of winter wheat. Agricult. Water Manag., 154, 59-67.

Lorenzo H., Perez-Gracia V., Novo A., and Armesto J., 2010. Forestry applications of ground-penetrating radar. Forest Syst., 19, 5-17.

Mahmoudzadeh M., Francés A., Lubczynski M., and Lambot S., 2012. Using ground penetrating radar to investigate the water table depth in weathered granites-Sardon case study, Spain. J. Appl. Geophys., 79, 17-26.

Maierhofer C., 2003. Nondestructive evaluation of concrete infrastructure with ground penetrating radar. J. Materials Civil Eng., 15, 287-297.

McDonald K.C., Zimmermann R., and Kimball J.S., 2002. Diurnal and spatial variation of xylem dielectric constant in Norway spruce (Picea abies [L.] Karst.) as related to microclimate, xylem sap flow, and xylem chemistry. IEEE Trans. Geosci. Remote Sens., 40, 2063-2082.

Moore G. and Ryder C., 2015. The use of ground-penetrating radar to locate tree roots. Arbori. Urban For., 41, 245-259.

Morison J.I., Baker N.R., Mullineaux P.M., and Davies W.J., 2008. Improving water use in crop production. Philos. Trans. R. Soc. London B: Biol. Sci., 363, 639-658.

Nanni M.R. and Demattê J.A.M., 2006. Spectral reflectance methodology in comparison to traditional soil analysis. Soil Sci. Soc. Am. J., 70, 393-407.

Novakova E., Karous M., Zajíček A., and Karousova M., 2013. Evaluation of ground penetrating radar and vertical electrical sounding methods to determine soil horizons and bedrock at the locality Dehtáŕe. Soil Water Res., 8, 105-112.

Olhoeft G.R., 2000. Maximizing the information return from ground penetrating radar. J. Appl. Geophys., 43, 175-187.

Ortuani B., Benedetto A., Giudici M., Mele M., and Tosti F., 2013. A non-invasive approach to monitor variability of soil water content with electromagnetic methods. Proc. Environ. Sci., 19, 446-455.

Oskooi B., Julayusefi M., and Goudarzi A., 2014. GPR noise reduction based on wavelet thresholdings. Arab. J. Geosci., 8, 2937-2951.

Pan X., Wollschläger U., Gerhards H., and Roth K., 2012. Optimization of multi-channel ground-penetrating radar for quantifying field-scale soil water dynamics. J. Appl. Geophys., 82, 101-109.

Pomfret J., 2006. Ground-penetrating radar profile spacing and orientation for subsurface resolution of linear features. Archaeol. Prospect., 13, 151-153. 
Qin Y., Chen X., Zhou K., Klenk P., Roth K., and Sun L., 2013. Ground-penetrating radar for monitoring the distribution of near-surface soil water content in the Gurbantünggüt Desert. Environ. Earth Sci., 70, 2883-2893.

Ramirez A., Daily W., Binley A., LaBrecque D., and Roelant D., 1996. Detection of leaks in underground storage tanks using electrical resistance methods. J. Environ. Eng. Geophys., 1, 189-203.

Raper R.L., Asmussen L., and Powell J.B., 1990. Sensing hard pan depth with ground-penetrating radar. Trans. ASAE, 33, 41-46.

Raz-Yaseef N., Koteen L., and Baldocchi D.D., 2013. Coarse root distribution of a semi-arid oak savanna estimated with ground penetrating radar. J. Geophys. Res.- Biogeosci., 118, 135-147.

Rea J. and Knight R., 1998. Geostatistical analysis of groundpenetrating radar data: a means of describing spatial variation in the subsurface. Wat. Resources Res., 34, 329-339.

Rhoades J. and Corwin D., 1981. Determining soil electrical conductivity-depth relations using an inductive electromagnetic soil conductivity meter. Soil Sci. Soc. Am. J., 45, 255-260.

Ritsema C.J. and Dekker L.W., 1998. Three-dimensional patterns of moisture, water repellency, bromide and $\mathrm{pH}$ in a sandy soil. J. Contam. Hydrol., 31, 295-313.

Robinson D.A., Campbell C.S., Hopmans J.W., Hornbuckle B.K., Jones S.B., Knight R., Ogden F., Selker J., and Wendroth O., 2008. Soil moisture measurement for ecological and hydrological watershed-scale observatories: A review. Vadose Zone J., 7, 358-389.

Saito H. and Kitahara M., 2012. Analysis of changes in soil water content under subsurface drip irrigation using ground penetrating radar. Desert Res., 22, 283-286.

Salucci M., Tenuti L., Nardin C., Oliveri G., Viani F., Rocca P., and Massa A., 2014. Civil Engineering Applications of Ground Penetrating Radar Recent Advances@the ELEDIA Research Center. EGU General Assembly Conference Abstracts, 16, 1945.

Schmelzbach C., Tronicke J., and Dietrich P., 2012. Highresolution water content estimation from surface-based ground-penetrating radar reflection data by impedance inversion. Wat. Resources Res., 48, W08505.

Seversike T., Sermons S., Sinclair T., Carter T., and Rufty T., 2014. Physiological properties of a drought-resistant wild soybean genotype: Transpiration control with soil drying and expression of root morphology. Plant Soil, 374, 359-370

Sharma S.P., Leskovar D.I., Crosby K.M., Volder A., and Ibrahim A., 2014. Root growth, yield, and fruit quality responses of reticulatus and inodorus melons (Cucumis melo L.) to deficit subsurface drip irrigation. Agricult. Water Manag., 136, 75-85.

Shih S.F. and Doolittle J.A., 1984. Using radar to investigate organic soil thickness in the Florida Everglades. Soil Sci. Soc. Am. J., 48, 651-656.

Stoffregen H., Zenker T., and Wessolek G., 2002. Accuracy of soil water content measurements using ground penetrating radar: comparison of ground penetrating radar and lysimeter data. J. Hydrol., 267, 201-206.
Stoops W., 1934. The dielectric properties of cellulose. J. Am. Chem. Soc., 56, 1480-1483.

Sucre E.B., Tuttle J.W., and Fox T.R., 2011. The use of groundpenetrating radar to accurately estimate soil depth in rocky forest soils. Forest Sci., 57, 59-66.

Tanikawa T., Hirano Y., Dannoura M., Yamase K., Aono K., Ishii M., Igarashi T., Ikeno H., and Kanazawa Y., 2013. Root orientation can affect detection accuracy of groundpenetrating radar. Plant Soil, 373, 317-327.

Thompson S.M., 2014. Evaluation of terrestrial laser scanning and ground penetrating radar for field-based high-throughput phenotyping in wheat breeding. Doctoral dissertation, Texas A\&M University. Available electronically from http://hdl.handle.net/1969. 1/153661.

Thompson S.M., Cosssani C.M., Ibrahim A.M.H., Reynolds M.P., Goodman D., and Hays D.B., 2013. Estimating wheat root biomass using ground penetrating radar. https:// dl.sciencesocieties.org/publications/meetings/download/ $\mathrm{pdf} / 2013 \mathrm{am} / 78536$

Topp G., Davis J., and Annan A.P., 1980. Electromagnetic determination of soil water content: Measurements in coaxial transmission lines. Wat. Resources Res., 16, 574-582.

Tosti F., Patriarca C., Slob E., Benedetto A., and Lambot S., 2013. Clay content evaluation in soils through GPR signal processing. J. Appl. Geophys., 97, 69-80.

Tran A.P., Ardekani M.R.M., and Lambot S., 2012. Coupling of dielectric mixing models with full-wave ground-penetrating radar signal inversion for sandy-soil-moisture estimation. Geophys., 77, H33-H44.

Tran A.P., Bogaert P., Wiaux F., Vanclooster M., and Lambot S., 2015. High-resolution space-time quantification of soil moisture along a hillslope using joint analysis of ground penetrating radar and frequency domain reflectometry data. J. Hydrol., 523, 252-261.

Truman C., Perkins H., Asmussen L., and Allison H., 1988. Using ground-penetrating radar to investigate variability in selected soil properties. J. Soil Water Conserv., 43, 341-345.

Upchurch D. and Ritchie J., 1983. Root observations using a video recording system in mini-rhizotrons. Agron. J., 75, 1009-1015.

Van Dam R.L., 2014. Calibration functions for estimating soil moisture from GPR dielectric constant measurements. Comm. Soil Sci. Plant Anal., 45, 392-413.

Veihmeyer F. and Hendrickson A., 1946. Soil density as a factor in determining the permanent wilting percentage. Soil Sci., $62,451-456$.

Wagner W., Lemoine G., and Rott H., 1999. A method for estimating soil moisture from ERS scatterometer and soil data. Remote Sens. Environ., 70, 191-207.

Walker J.S., 2008. A Primer on Wavelets and Their Scientific Applications. CRC Press, Boca Raton, FL. USA.

Wang B., Zhang W., Ahanbieke P., Gan Y., Xu W., Li L., Christie P., and Li L., 2014. Interspecific interactions alter root length density, root diameter and specific root length in jujube/wheat agroforestry systems. Agroforest. Syst., 88, 835-850.

Wang L. and Qu J.J., 2009. Satellite remote sensing applications for surface soil moisture monitoring: A review. Front. Earth Sci. China, 3, 237-247. 
Wang Y., Zhang X., Liu X., Zhang X., Shao L., Sun H., and Chen S., 2013. The effects of nitrogen supply and water regime on instantaneous WUE, time-integrated WUE and carbon isotope discrimination in winter wheat. Field Crops Res., 144, 236-244.

Wang Z., Ma B.L., Gao J.L., and Sun J.Y., 2015. Effects of different management systems on root distribution of maize. Can. J. Plant Sci., 95, 21-28.

Wasson A., Richards R., Chatrath R., Misra S., Prasad S.S., Rebetzke G., Kirkegaard J., Christopher J., and Watt M., 2012. Traits and selection strategies to improve root systems and water uptake in water-limited wheat crops. J. Exp. Bot., 63, 3485-3498.

Weaver W., 2006. Ground-penetrating radar mapping in clay: Success from Soth Carolina, USA. Archaeol. Prospect., 13, $147-150$

Weihermüller L., Huisman J., Lambot S., Herbst M., and Vereecken H., 2007. Mapping the spatial variation of soil water content at the field scale with different ground penetrating radar techniques. J. Hydrol., 340, 205-216.

Welbank P. and Williams E., 1968. Root growth of a barley crop estimated by sampling with portable powered soil-coring equipment. J. Appl. Ecol., 5, 477-481.

West L.J., Handley K., Huang Y., and Pokar M., 2003. Radar frequency dielectric dispersion in sandstone: Implications for determination of moisture and clay content. Wat. Resources Res., 39, 1026.

Wielopolski L., Hendrey G., Daniels J.J., and McGuigan M., 2000. Imaging tree root systems in situ (Eds D.A. Noon, G.F. Stickley, D. Longstaff). Proc. 8th Int. Conf. GroundPenetrating radar, Gold Coast, Queensland, Australia, May 23-26. Proc. SPIE Int. Society of Optical Engineering, Bellingham, WA, USA.

Wijewardana Y., Galagedara L., Mowjood M., and Kawamoto K., 2015. Assessment of inorganic pollutant contamination in groundwater using ground penetrating radar (GPR). Trop. Agricult. Res., 26, 700-706.
Winkelbauer J., Völkel J., Leopold M., and Bernt N., 2011. Methods of surveying the thickness of humous horizons using ground penetrating radar (GPR): an example from the Garmisch-Partenkirchen area of the Northern Alps. Eur. J. Forest Res., 130, 799-812.

Yadav B.K. and Mathur S., 2008. Modeling soil water uptake by plants using nonlinear dynamic root density distribution function. J. Irrig. Drain. Eng., 134, 430-436.

Yeung S.W., Yan W.M., and Hau C.H.B., 2016. Performance of ground penetrating radar in root detection and its application in root diameter estimation under controlled conditions. Sci. China Earth Sci., 59, 145-155.

Yoder R.E., Freeland R.S., Ammons J.T., and Leonard L.L., 2001. Mapping agricultural fields with GPR and EMI to identify offsite movement of agrochemicals. J. Appl. Geophys., 47, 251-259.

Zaman-Allah M., Jenkinson D.M., and Vadez V., 2011. A conservative pattern of water use, rather than deep or profuse rooting, is critical for the terminal drought tolerance of chickpea. J. Exp. Bot., 62, 4239-4252.

Zenone T., Morelli G., Teobaldelli M., Fischanger F., Matteucci M., Sordini M., Armani A., Ferrè C., Chiti T., and Seufert G., 2008. Preliminary use of ground-penetrating radar and electrical resistivity tomography to study tree roots in pine forests and poplar plantations. Funct. Plant Biol., 35, 1047-1058.

Zhang X., Chen S., Sun H., Wang Y., and Shao L., 2009. Root size, distribution and soil water depletion as affected by cultivars and environmental factors. Field Crops Res., 114, 75-83.

Zhang X., Shao L., Sun H., Chen S., and Wang Y., 2012. Incorporation of soil bulk density in simulating root distribution of winter wheat and maize in two contrasting soils. Soil Sci. Soc. Am. J., 76, 638-647.

Zhang X., Zhang X., Liu X., Shao L., Sun H., and Chen S., 2015. Incorporating root distribution factor to evaluate soil water status for winter wheat. Agricult. Water Manag., 153, $32-41$.

Zhu S., Huang C., Su Y., and Sato M., 2014. 3D ground penetrating radar to detect tree roots and estimate root biomass in the field. Remote Sens., 6, 5754-5773. 